https://dx.doi.org/10.4314/ijs.v19i2.13

Ife Journal of Science vol. 19, no. 2 (2017)

\title{
MICROBIAL CONTAMINATION OF SHEA (VITELLARIA PARADOXA G. DON) BUT'TER FROM LOCAL MARKETS IN SOUTHWESTERN AND EDO STATES, NIGERIA
}

\author{
${ }^{1 *}$ Samuel, T. O. and ${ }^{2}$ Egwuatu, T. O. G and ${ }^{3}$ Ebabhi, A. M. \\ ${ }^{1}$ Department of Botany, University of Lagos, Akoka, Lagos State \\ ${ }^{2}$ Department of Microbiology, University of Lagos, Akoka, Lagos State \\ ${ }^{3}$ Distance Learning Institute, University of Lagos, Akoka, Lagos State \\ *Corresponding author: Tel: 2348036410449 E-mail: tosamuel@unilag.edu.ng; temmitade@yahoo.com \\ (Received: $5^{\text {th }}$ April, 2017; Accepted: $2^{\text {nd }}$ October, 2017)
}

ABSTRACT

\begin{abstract}
Samples of Shea butter were randomly collected from five local markets from four different states in Nigeria. Isolation and identification of microbial contaminants (Bacteria and Fungi) were carried out as well as the analysis of some physical and chemical parameters. Results from this study reveal the presence of five fungal and three bacterial species as contaminants. The isolated fungi include: Aspergillus niger, Aspergillus flavus, Fusarium species, Mucor species and Trichoderma species. Citrobacter freundii, Escherichia coli and Pseudomonas aeruginosa were the bacteria established in the study. Differences were also noted in the colour, refractive index and the viscosity of the shea butters sampled. A great significant differences was also observed in the peroxide $(2.0-8.60$ $\mathrm{meq} / \mathrm{kg})$, saponification $(29.21-47.48 \mathrm{mgKOH} / \mathrm{g})$, iodine $(4.31-13.20 \mathrm{I} \mathrm{g} / 100 \mathrm{~g})$ and the fatty acid $(27.50-$ $88.83 \mathrm{mgKOH} / \mathrm{kg}$ ) values respectively. It was deduced from this study that hawked Vitelleria paradoxa (Shea butter) in our local markets are heavily contaminated with microbes (fungi and bacteria) and this may be detrimental to the health of the users especially those with wounds on their skin.
\end{abstract}

Keywords: Microbial contaminant, shea butter, local market, physicochemical parameters

\section{INTRODUCTION}

Shea butter is a cream coloured fat extracted from the nut of Vitellaria paradoxa G Don. (formerly known as Butyrospermum parkii) which belongs to the family Sapotaceae (Henry et al., 1983). Vitellaria paradoxa is one of the most important sources of vegetable oil in rural areas of the savanna zone of West Africa (Moore, 2008). In Nigeria, $90 \%$ of Shea butter processors are married women and majority of them have no formal education (Ademola et al., 2012). Shea butter is one of the useful raw materials in the pharmaceutical and cosmetic industries. It is used as a precursor for the manufacture of soaps, candles and cosmetics (Fobil, 2010). A large population of Nigerian natives use Shea butter to control various skin disorders. They believe this natural plant extract is almost magical in its healing effects on burns, skin rashes, ulcerated skin, stretch marks, wrinkles, acne, eczema and dryness (Maranz et al., 2004). They also believe Shea butter to contain beneficial vegetable fats that promote cell regeneration and circulation, thereby making aging and troubled skin to rejuvenate (Esiegbuya $e t$ al., 2014).
Recently, there have been complaints from many users on the emergence of skin rashes from the topical usage of some purchased Shea butter from our local markets. This study aims to screen Shea butter from different locations for the presence of microbial contaminant (if any) that may be responsible for the skin rashes and also, to investigate some physicochemical parameters of each collected Shea butter sample.

\section{MATERIALS AND METHODS}

\section{Shea butter used}

Some quantity of Shea butter ( $50 \mathrm{~g})$ was purchased at five local markets in four states of the western region of Nigeria. The markets include: Ajah market $\left(6^{\circ} 28^{\prime} 06^{\prime \prime} \mathrm{N} ; 3^{\circ} 33^{\prime} 50^{\prime \prime} \mathrm{E}\right)$ and Idumota market (6 $\left.6^{\circ} 27^{\prime} 16^{\prime \prime} \mathrm{N} ; 3^{\circ} 23^{\prime} 31^{\prime \prime} \mathrm{E}\right)$ in Lagos State, Mokola market $\left(7^{\circ} 23^{\prime} 16^{\prime \prime} \mathrm{N} ; 3^{\circ} 53^{\prime} 47^{\prime \prime} \mathrm{E}\right)$ in Ibadan, Oyo State, Oke-Aje market (6 $6^{\circ} 48^{\prime} 57^{\prime \prime} \mathrm{N}$; $\left.3^{\circ} 54^{\prime} 57^{\prime \prime} \mathrm{E}\right)$, Ijebu Ode, Ogun State and Usele market $\left.6^{\circ} 19^{\prime} 60^{\prime \prime} \mathrm{N} ; 5^{\circ} 37^{\prime} 60^{\prime \prime} \mathrm{E}\right)$, Edo State. Three different retailers were patronised randomly at each mentioned market. A branded Shea butter (Unique Natural Premium Shea Butter) was also purchased at a Super mart store in Akoka, Yaba, Lagos State, Nigeria. 


\section{Preparation of Medium}

Commercially produced Potato dextrose agar, PDA (Oxoid, Basingstoke, England) and Nutrient agar, NA (Oxoid, Basingstoke, England) were prepared according to manufacturer specification and these were used as primary isolation media.

\section{Isolation of Microbial Contaminants from the Sample Shea butters}

Isolation of Fungi

Potato dextrose agar (PDA) was used as the medium for the antifungal assay. The medium (20 g) was prepared according to manufacturer's specification. Two drops of lactic acid was added to the prepared PDA. This is to inhibit the growth of any chanced bacterium present. The method of Adekunle and Ozonweke (2001) was adopted here. This involved melting of about twenty grams of each purchased Shea butter in a graduated beaker placed in a water bath. After melting, $3 \mathrm{ml}$ of the melted Shea butter oil sample was added to $15 \mathrm{ml}$ of Potato dextrose agar (PDA) and the mixture was poured into a sterile Petri dish. This experiment was carried out in triplicate on each of the three types of Shea butter from each market. The poured plates were incubated at $30{ }^{\circ} \mathrm{C}$ aerobically. Each plate was labelled with necessary information such as name of market of purchase, retailer number and time of inoculation. Culture plates were examined daily for any observable growth.

\section{Isolation of Bacteria}

Nutrient agar (NA) was used as the medium for the antibacterial assay. The medium was prepared according to manufacturer's specification. Fifty milligram of fulcin was dissolved in the prepared $500 \mathrm{ml} \mathrm{NA}$. This is to inhibit the growth of any chanced fungi present. The method of Adekunle and Ozonweke (2001) was also adopted here. This involved melting of about twenty grams of each purchased Shea butter in a graduated beaker placed in a water bath. After melting, $3 \mathrm{ml}$ of the oil sample was added to $15 \mathrm{ml}$ of nutrient agar (NA) and the mixture was poured into a sterile Petri dish. This experiment was carried out in triplicate on each of the three types of Shea butter from each market. The poured plates were incubated at $30{ }^{\circ} \mathrm{C}$ aerobically. Each plate was labelled as previously described. Culture plates were examined daily for any observable growth.

\section{Identification of Isolated Microbes}

Identification of fungi

A little portion of the growth colony was teased with a sterile inoculation needle and mounted in a drop of Methyl-Blue on a clean microscope slide. Covered with a cover slip, this was squashed with the butt of the inoculation needle and the excess fluid then blotted off. The preparation was examined under a light microscope with an attached camera (Motic McCamera [2000] 2.0 megapixel digital coloured camera) connected to a computer, for the microscopic photograph of the fungi. This was to observe the precise arrangement of the conidiophore and the way in which their spores are produced. The identities of these fungi were certified using their cultural, morphological characteristics as well as comparing them with confirmed representatives of different species in relevant texts such as Alexopolous etal. (2007) and Watanabe (2002).

Identification of bacteria

\section{Gram staining}

The sub-cultured bacterium strain was identified using Gram staining method. A few drops of crystal violet was added onto the smear of the bacterium on a sterile glass slide for a minute, after which the excess stain was rinsed off using flowing water, Lugols iodine solution was added for 60 seconds. This was also rinsed off using flowing water. The smear was decolorized by adding 70\% ethanol and counter stained with Safranin. A drop of oil immersion was added after which the slide was observed under the oil immersion objective lens.

\section{Biochemical tests}

This test was further used to confirm the identity of the bacteria isolates and was achieved using Indole and citrate tests described by Tankeshwar (2013). Indole production is detected by Kovac's reagent which contains 4(p)-dimethy laminobenzaldehyde, this reacts with the indole to produce a red colouration compound on the confirmation of gram positive bacteria. For citrate test, Simmons citrate agar was used and this is to test the ability of the bacteria to utilize sodium citrate as its only carbon source and inorganic salts as the sole nitrogen source. 


\section{Physicochemical Analysis}

Physical characteristics

The colour of the sample Shea butters were physically assessed by visual inspection. Refractive index was determined using a refractometer and viscosity was determined using a viscometer (AOAC, 1997).

\section{Chemical Characteristics}

Saponification, iodine, peroxide and acid values were determined using the standard method described by AOAC (1997).

Saponification value: Five grams of each shea butter samples was added to different flask with 60 $\mathrm{ml}$ of ethanolic potassium hydroxide and was then attached to a condenser for $30 \mathrm{mins}$ to dissolve shea butter samples completely. Each sample mixture was allowed to cool, then $1 \mathrm{ml}$ of phenolphthalein was added and titrated with 0.5 $\mathrm{M}$ hydrochloride until a pink end point was reached. Saponification value (SV) was calculated using the equation below:

$\mathrm{SV}=(\mathrm{S}-\mathrm{B}) \times \mathrm{M} \times 56.1 /$ Sample weight $(\mathrm{g})$

Where, $\mathrm{S}=$ sample titre value;

$\mathrm{B}=$ blank titre value;

$\mathrm{M}=$ molarity of the $\mathrm{HCl}$;

$56.1=$ molecular weight of $\mathrm{KOH}$

Iodine value: Five grams of each Shea butter samples was weighed into different conical flasks and $50 \mathrm{ml}$ of carbon tetra chloride was added to dissolve samples. Fifty millilitre of Dam's reagent was then added to the flask using a safety pipette in fume chamber. Stopper was inserted and the content of the flask was vigorously swirled. The flask was then placed in the dark for 150 mins then $25 \mathrm{ml}$ of $10 \%$ aqueous potassium iodide and 125 $\mathrm{ml}$ of water were added using a measuring cylinder. This mixture was titrated with $0.1 \mathrm{M}$ sodium thiosulphate solutions until the yellow colour disappeared. A few drops of $1 \%$ starch indicator was added and the titration continued by adding thiosulphate drop wise until blue coloration disappeared after vigorous shaking.

The iodine value (IV) is calculated using the below equation:

$\mathrm{IV}=12.69 \mathrm{C}\left(\mathrm{V}_{1}-\mathrm{V}_{2}\right) / \mathrm{M}$

Where, $\mathrm{C}=$ concentration of sodium

$\mathrm{V}_{1}=$ volume of sodium thiosulphate used for blank;

$\mathrm{V}_{2}=$ volume of sodium thiosulphate used for determination

and $\mathrm{M}=$ mass of the sample.

Acid value: Five grams of each Shea butter samples was weighed into different $500 \mathrm{ml}$ beakers and $50 \mathrm{ml}$ of neutral ethyl alcohol was added and heated to boil. The mixture was then titrated with $\mathrm{N} / 10 \mathrm{KOH}$ solution, using two drops of phenolphthalein as indicator with consistent shaking until a pink colouration was obtained as the end point.

The acid value (AV) was calculated as follows. AV $=0.56 \times$ No. of $\mathrm{ml} \mathrm{N} / 10 \mathrm{KOH}$ used

Peroxide value: Five grams of each sampled shea butter was weighed into different $500 \mathrm{ml}$ conical flask with a glass stopper. Then $30 \mathrm{ml}$ of $3: 2 \mathrm{v} / \mathrm{v}$ glacial acetic acid-chloroform solvent was added to each flask containing sampled Shea butter and swirled to dissolve the sample. One $\mathrm{ml}$ of saturated KI solution was added to each set up. The mixtures were left in the dark with occasional stirring for exactly $1 \mathrm{~min}$, and $30 \mathrm{ml}$ of distilled water added immediately. The mixture was titrated with $0.1 \mathrm{~N}$ sodium thiosulphate using $0.5 \mathrm{ml}$ of starch indicator solution. A blank was also performed at the same time.

The peroxide value (PV) was calculated using the equation below:

$\mathrm{PV}=1000\left(\mathrm{~V}_{1}-\mathrm{V}_{2}\right) \mathrm{XN} / \mathrm{W}$

Where $\mathrm{N}=$ normality of $\mathrm{Na}_{2} \mathrm{~S}_{2} \mathrm{O}_{3}$ solution, $\mathrm{V}_{1}=$ volume $(\mathrm{ml})$ of $\mathrm{Na}_{2} \mathrm{~S}_{2} \mathrm{O}_{3}$ solution used in test, $\mathrm{V}_{2}=$ volume $(\mathrm{ml})$ of $\mathrm{Na}_{2} \mathrm{~S}_{2} \mathrm{O}_{3}$ solution used in blank,

$\mathrm{W}=$ weight of oil sample.

\section{RESULTS}

Forty-eight hours after the incubation of the seeded plates of growth media (PDA) with sample Shea butter, noticeable colonies of fungi were seen on some incubated PDA plates. These colonies of fungi were sub-cultured to pure culture of isolated fungi. Four fungi genera were isolated and these include: Aspergillus flavus, Fusarium spp, Mucorspp and Trichoderma spp (Table 1a). No growth/colony was observed on the media plates seeded with the branded Shea butter tested.

Twenty-four hours after incubation of the seeded 
nutrient agar plates with sample Shea butter, colonies emerged on the seeded culture plates. Results from the gram staining and the biochemical test on the isolated bacteria revealed three bacteria species, namely; Citrobacter freundii,
Escherichia coli and Pseudomonas aeruginosa (Table 1b). The seeded nutrient agar plates showed no growth with the branded Shea butter at the end of the incubation period ( $72 \mathrm{hrs}$ ).

Table 1a: Isolated Fungi

\begin{tabular}{llll}
\hline & Isolated Fungi & & \\
Markets (Location) & Sample 1 & Sample 2 & Sample 3 \\
\hline Ajah & Fusarium species & Mucor species & Mucor species \\
Idumota & Trichoderma species & Aspergillus niger & Mucor species \\
Oke Aje & Mucor species & Mucor species & Mucor species \\
Mokola & Aspergillus flavus & Mucor species & Fusarium \\
Usele & Mucor species & Trichoderma species & Trichoderma species \\
\hline
\end{tabular}

Table $1 \mathrm{~b}$ : Isolated Bacteria

\begin{tabular}{llll}
\hline Markets & $\begin{array}{l}\text { Isolated Bacteria } \\
\text { Sample 1 }\end{array}$ & Sample 2 & Sample 3 \\
\hline Ajah & Citrobacter freundii & No growth & Citrobacter freundii \\
Idumota & Escherichia coli & Escherichia coli & Pseudomonas aeruginosa \\
Oke Aje & P. aeruginosa & P. aeruginosa & P. aeruginosa \\
Mokola & Citrobacter freundii & No growth & No growth \\
Usele & P. aeruginosa & Escherichia coli & P. aeruginosa \\
\hline
\end{tabular}

It was observed that Mucor spp had the highest frequency of occurrence as it was found in samples from each station surveyed. In the bacteria group, Pseudomonas aeruginosa had the highest frequency of occurrence, being found in three of the five stations that were surveyed.

The results from physicochemical parameters of the five sampled Shea butter reveal that there is variation in their colours (Table 2a). Variation was also noted in the refractive index with the values ranging from 0.89 to 2.66 and viscosity with values of 0.27 to 5.87 (Table $2 a$ ).

On the chemical properties of the five sampled Shea butter, variations were noticed in their chemical properties. The Shea butter sample from Mokola in Oyo State displayed the lowest value of peroxide, saponification and iodine but with highest acid value (Table $2 \mathrm{~b}$ ). While the sample from Usele in Edo State showed the lowest acid value but possesses the highest saponification and iodine values.

Table 2 a: Physical parameters of Shea butter samples

\begin{tabular}{llll}
\hline Sample (Shea butter) & Colour & Refractive Index & Viscosity (cP) \\
\hline Ajah & Blonde & 1.1886 & 5.811 \\
Idumota & Butter & 1.1289 & 5.861 \\
Oke Aje & Yellow & 1.0675 & 5.876 \\
Mokola & Lemon & 2.6516 & 5.712 \\
Usele & Greyish yellow & 0.8898 & 0.267 \\
& & \\
\hline
\end{tabular}


Table 2 b: Chemical characteristics of Shea butter samples

\begin{tabular}{lllll}
\hline $\begin{array}{l}\text { Sample } \\
\text { (Shea butter) }\end{array}$ & $\begin{array}{l}\text { Peroxide value } \\
(\mathbf{m e q} / \mathbf{k g})\end{array}$ & $\begin{array}{l}\text { Saponification } \\
\text { value } \\
(\mathbf{m g K O H} / \mathbf{g})\end{array}$ & $\begin{array}{l}\text { Iodine value } \\
\left(\mathbf{I}_{2 \mathbf{g}} / \mathbf{1 0 0 g}\right)\end{array}$ & $\begin{array}{l}\text { Acid value } \\
(\mathbf{m g K O H} / \mathbf{k g})\end{array}$ \\
\hline A - Ajah & 8.60 & 42.20 & 8.60 & 84.21 \\
B - Idumota & 8.20 & 43.34 & 6.92 & 85.66 \\
C - Oke Aje & 8.60 & 39.43 & 8.40 & 80.37 \\
D - Mokola & 2.00 & 29.21 & 4.31 & 88.83 \\
E - Usele & 8.40 & 47.48 & 13.20 & 27.50 \\
\hline
\end{tabular}

\section{DISCUSSION AND CONCLUSION}

Different parts of the Shea tree including leaves, roots, seeds, fruit and stem bark serve varying purposes to mankind (Garba et al., 2011). The bark is used to suppress cough and also to treat leprosy (Ferry et al,1974). Shea nut contains about $60 \%$ fat and together with the oil palm serve as sources of edible oil for many households in many parts of the Sahel Africa, particularly Northern Nigeria (Ademola et al., 2012; Garba et al., 2015). Shea butter is well known for its use as a component of cosmetic formulations (Maranz et al. 2004). However, reports from Ghana (Issahaku et al., 2011) through Republic of Benin (Honfo et al., 2011) to Nigeria (Ademola et al., 2012; Garba et al., 2015) affirms the production of Shea butter mainly through traditional methods passed down through generational line. Results from this present study revealed that all the sampled Shea butter contain loads of microbial contaminants compared to the branded Shea butter sample used in the study which showed no microbial growth. According to Ademola et al., (2012), majority of the Shea butter processors especially in western part of Nigeria are women with no formal education, inferring illiteracy and difficulties in accepting innovation. Therefore, hygienic practices during processing are low.

Fungal and bacterial species were isolated from the samples under study. Studies by Esiegbuya $\mathrm{et} \mathrm{al}$. (2014) reported that post-harvest fungal contaminants such as Aspergillus, Fusarium, Phoma and Mucor species were discovered from the kernels and nuts of the Shea plant. These groups of fungal species were also isolated during the course of this study. This could have been as a result of the storage duration or storage materials used in packaging the Shea butter, affirming Honfo et al. (2011) who observed that increase in microbial load of the Shea butter increases with storage duration and the nature of package materials. Esiegbuya et al. (2014) revealed that microbial contaminants caused colour deterioration and tainting of the Shea nut and kernel. This could have led to the variation in colours observed in the Shea butter samples used in this study, which is in agreement with Global Shea Alliance (2013). The isolated fungi could have penetrated the Shea butter since they are able to produce lipase that can cause enzymatic hydrolysis of the butter. Womeni et al. (2006) and Megnagnou et al. (2007) also in their reports stated that hydrolysis and oxidation reactions during the extraction processes of Shea butter varies, and uncontrolled in the traditional pre-treatments, and these in turn, alter the quality and variability of the Shea butter produced.

According to Klich (2002), the fungi encountered in the present study are associated with human skin infections which include superficial and cutaneous mycosis. Most fungi may gain entry through wounds or cracked skin during application of the contaminated Shea butter. Mucor species are well known to suppress immunity especially in diabetic and cancer patients. These microbial contaminants could also be consumed with the Shea butter. It has been reported that the consumption of Shea nut and kernel is on the increase due to high cost of imported oil (Okullo et al. 2010 and Honfo et al. 2011). The butter serves as source of fatty acids and glycerol in many diets (Letchamo et al., 2007). The bacterial species like $P$. aeruginosa and E. coli isolated during this study are also known to cause infection especially in patients with compromised host defense mechanisms (Wanke, 2001; Sousa and Pereira, 2014).

The Shea butter physicochemical parameters obtained in this study indicated that the sampled 
Shea butter is undergoing some degree of deterioration, which could have been due to the post-production handling processes and storage materials used. As observed by Honfo et al., (2011), peroxide value and iodine value also increased with days. Deterioration could also be due to invasion by microbial contaminants as reported by Esiegbuya et al. (2014).

Peroxide value greater than 2 meq according to ASBI (2012) is an indicative of significant oxidative destruction. It is also reported that high values of peroxide are seen in poor quality Shea butter. Only sample from Mokola market in this study has peroxide value of 2 meq while others have above the recommended value. Same was applicable to fatty acids, which according to the ASBI (2012), the acceptable limit is $2 \%$ and the higher the fatty acids, the more damage it can cause to the skin. All the surveyed Shea butter samples in this present study have far higher values than the acceptable limit.

In conclusion, the results from this study show that hawked Vitellaria paradoxa (Shea butter) in our local markets are heavily contaminated with microbes (both fungi and bacteria). These microbes may probably be responsible for the skin rashes often noticed by users on their skins. As a result of the contamination, we also suggest that hawked Shea butter may be detrimental to the health of users especially those with wounds or cuts on their skins.

\section{REFERENCES}

Adekunle, A. A. and Ozonweke, M.C. 2001. Production and preservation of body and hair cream from soybean seed oil in Nigeria. Journal of Science, Technology and Environment 1, 57 - 66

Ademola, A.O., Oyesola, O.B. and Osewa, S.O. 2012. Assessment of shea butter processing among rural dwellers in Atisbo Local Government area of Oyo State, Nigeria. European Journal of Business and Social Sciences 1(6), 1-8

Alexopolous, C.J., Mims, C.W. and Blackwell, M. (2007). Introductory Mycology. Fourth edition. Wiley India, New Delhi. 869pp

ASB1 (American Shea Butter Institute). (2012). Processing and storage of shea butter and shea based products. Shea Tech Certification Study Guide ASBI, USA. 26 pp

AOAC (Association of Official Analytical Chemists). 1997. Official methods of analysis. $17^{\text {th }}$ ed. Washington, DC.

Esiegbuya D. O., Osagie J. I., Okungbowa F. I. and Ekhorutomwen, E. O. 2014. Fungi Associated with the Postharvest Fungal Deterioration of Shea Nuts and Kernels International Journal of Agriculture and Forestry 4(5), 373-379

Ferry, M. P., Gessain, M. and Geeain, R. 1974. Vegetative Propagation of Shea, Kola and Pentadesma. Cocoa Research Institute Ghana AnnualReport Pp 98-100.

Fobil, J. N. 2010. Research and development of the shea tree and its products. In:HORIZON International, New Haven, USA.

Garba, I. D., Nwawe, C.N. and Oisakede, I. L. 2011. The Potentials of Shea Nut Tree to the Nigerian Economy. International Journal of Agricultural Economics and Rural Development 4(1), 62 - 72

Garba, I. D., Sanni, S. A. and Adebayo, C. O. 2015. Analyzing the Structure and Performance of Shea Butter Market in Bosso and Borgu Local Government Areas of Niger State. International Journal of Science and Technology 8(2), 321-336.

Global Shea Alliance. 2013. Industry Quality Standards for Shea kernel. Ghana. 14pp

Henry, A.N., Chithra, V. and Nair, N.C. 1983. Vitellaria vs. Butyrospermum (Sapotaceae). Taxon 32, 286

Honfo, F. G., Hell, K., Akissoé, N., Coulibaly, O., Fandohan, P. and Hounhouigan, J. 2011. Effect of storage conditions on microbiological and physicochemical quality of Shea butter. Journal of Food Science and Technology 48(3), 274-279.

Issahaku1, H., Ramatu, A. and Sarpong, D.B. 2011. An analysis of allocative efficiency of shea butter processing methods in the northern region of Ghana. Journal of Development and Agricultural Economics 3(4), 165-173.

Klich, M .A. 2002. Differentiation of Aspergillus flavus from Aspergillusparasiticus and other closely related species. Transaction British Mycological Society 91, 99-108. 
Letchamo, W., Khoo, B. K. and Hartman, T.G. 2007 Evaluation of the quality of West African Shea butter (Vitellaria paradoxa). International Society for Horticultural Science 756, 273-288.

Maranz, S., Weisman, Z., Bisgaard, J. and Bianchi, G. 2004. Germplasm resources of Vitellaria paradoxa based on variation in fat composition across the distribution range. Agroforestry Systems. 60, 71 - 76.

Megnagnou, R. M., Niamke, S. and Diopoh, J. 2007 . Physicochemical and microbiological characteristics of optimized and traditional shea butters from Côte d'Ivoire. African Journal of Biochemistry Research 1, 41 - 47.

Moore, S. 2008. The role of Vitellaria Paradoxa in poverty reduction and food security in the Upper East region of Ghana. Earth and Environment3, 209- 245

Okullo, J.B.L., Omujal, F., Agea, J.G., Vuzi, P.C., Namutebi, A., Okello, J.B.A. and and Nyanzi, S.A. 2010. Physico-Chemical Characteristics Of Shea Butter (Vitellaria paradoxa C.F. Gaertn) Oil from the Shea
Districts of Uganda. African Journal of Food Agriculture Nutrition and Development 10(1), 1684-5374.

Sousa, A. M. and Pereira, M. O. 2014. Pseudomonas aeruginosa Diversification during Infection Development in Cystic Fibrosis Lungs-A Review. Pathogens 3(3), 680-703.

Tankeshwar, A. 2013. Citrate utilization test: principle procedure, expected results and positive organisms. Microbe, 20-21.

Wanke, C.A. (2001). To Know Escherichia coli Is to Know Bacterial Diarrheal Disease. Clinical Infectious Diseases 32 (12), 17101712.

Watanabe, T. 2002. Pictorial Atlas of Soil and Seed Fungi. Morphologies of Cultured Fungi and Key to Species. $2^{\text {nd }} E d$. CRC Press, Boca Raton. $506 \mathrm{pp}$

Womeni, H.M., Ndjouenkeu, R., Kapseu, C., Tchouanguep, M. F, Parmentier, M.and Fanni, J. 2006. Effet de la cuisson et du séchage des noix de karité (Butyrospermum parkii (G. Don) Kotschy) sur la qualité du beurre. Tropicultura 24, 175-182. 